\title{
Learner Autonomy: Iraqi EFL Teachers’ Beliefs
}

\author{
Yaseen Alzeebaree, PhD candidate \\ Prof. Dr. Mehmet Yavuz, PhD \\ Cyprus International university/Cyprus
}

\begin{abstract}
doi: 10.19044/esj.2016.v12n31p59 URL:http://dx.doi.org/10.19044/esj.2016.v12n31p59
\end{abstract}
\begin{abstract}
Today students need to take responsibility for their own learning and be autonomous more than thirty years ago. Learner autonomy, which makes the learners more effective, has been given attention in the language learning process over the last three decades. The goal of this study is to explore Iraqi English teachers' beliefs about learner autonomy. The participants of the study consist of 116 EFL teachers (87 males and 29 females) from different academic (Diploma, Bachelor, Master and $\mathrm{PhD}$ ) and teaching (intermediate, secondary and university) levels. A questionnaire developed by Borg \& AlBusaidi (2012) is used to elicit the required data. Data is analyzed by using SPSS version 22. The results of the study reveal that EFL teachers have a positive attitude to some extent towards learner autonomy. The results of the study and their pedagogical implications are discussed, and recommendations for further research are provided.
\end{abstract}

Keywords: Learner autonomy, teachers’ beliefs, EFL teachers

\section{Introduction}

In a traditional classroom or teacher-centered education, teacher's role is central and active. The teacher models the target language, controls the direction and pace of learning. The teacher is seen as the primary source of knowledge and educational direction and the focal point in the classroom. The process of learning is all determined by the teacher. Kramsch and Sullivan (1996) claim that teachers are traditionally regarded as masters of knowledge in the classroom..In contrast, the students tend to be passive receiver in the classroom who are limited to listening and learning from the teacher. The teacher is the main figure in this model and the source of knowledge. While students are viewed as empty vessels whose primary role is to passively receive information. The teachers decide what to learn and how to learn. On the other hand, there has been increasing emphasis in recent 
years on moving away from traditional teaching toward student-centered learning in which teacher's role is restricted to a facilitator and counselor.

Learner autonomy has gained interest for nearly more than three decades. Grima, Cotterall and Palfreyman, (as cited in Borg \& Al-Busaidi, 2012) state that learner autonomy fosters language learning, enhances democracy in the society, forms learners for continuing learning and lets the learners benefit from learning inside and outside educational institutions. Students need to take responsibility for their own learning more than about three decades ago.

One of the significant topic in the twenty-first century is learner autonomy. It involves pedagogy development with the purpose of making a knowledgeable generation of youth by enabling them to take charge of their own learning in and out of educational institutions. It is inevitable for any pedagogical institution to equip learners with all information they need for their future, but it can arm learners with a general information regarding education process and communication as a way of improving continuously (Camilleri, 1999). Teachers and instructors should consider learner autonomy as an educational aim and create an appropriate environment to promote autonomy (Little, 2002).

Teachers are not only required to convey information to learners but also to stimulate learners to learn and guide them how to learn in an appropriate way (Rinantanti, 2015). Learner autonomy was originated by Holec, in 1981, who is considered as the father of learner autonomy (Shangarffam \& Ghazisaeedi, 2013).

The present study, hence, developed for the purpose of addressing the following research questions:

1. How do Iraqi EFL teachers perceive learner autonomy?

2. To what extent does learner autonomy contribute to second language learning?

3. What is the role of teacher in enhancing learner autonomy?

4. What does promote learner autonomy?

Very little has been written about autonomy and EFL learning success comparing to autonomy in language learning. Language learning has nearly become an indispensable part in human being life; therefore, pedagogical studies have stressed on the learner autonomy and responsibility the learners have to take for their own learning.

\section{Learner autonomy}

Autonomy is an old concept and is believed to date back to fifteenth and sixteenth centuries, but, learner autonomy did not appear in the field of language education until nearly the past thirty years ago. Autonomy was 
applied to states and institutions then later to individuals in the philosophy domain (Benson 2011, Benson and Voller 1997).

The term autonomy was originated from politics and moral philosophy. Autonomy means to be free, able and responsible to run your own activities that involves to be entitled to decide. It entails vigorous participation (Scharle, Szabo, 2000).

For Benson (2001) autonomy means as "the capacity to take control over one's own learning” (p. 47). Little (1991) defines autonomy as "the learner's psychological relation with the learning process and content" (p. 40). While for Dickinson (1987) learning autonomy implies a "situation in which the learner is totally responsible for all of the decisions concerned with his or her learning and the implementation of those decisions” (p. 11).

\section{Social and Personal Demand for Learner Autonomy}

Learner autonomy should be nurtured and endorsed for social and personal reasons. There is a necessity for the learners to be autonomous in cooperation with teachers that it is specified in to foster language sense, to obtain effective language learning methods and to enhance their self-learning abilities (The College English Teaching Syllabus, 1999). The world has been radically changed in ways that no one could have predicted hundred years ago. People are living in an amazing globalized world that one can hardly consume a new product as newer one soon is launched in the market; therefore, it has become necessary for every individual to update themselves with technology, new information, and skills (Wang, 2011). According to Rogers (1983): "The only man who is educated is the man who has learned how to learn; the man who has learned how to adapt and change; the man who has realized that no knowledge is secure, that only the process of seeking knowledge gives a basis for security (p. 120)”.

\section{Autonomy in The Classroom}

Traditionally, learner autonomy has been confined to places other than the classroom. But nowadays there is another understanding to this concept, in other words, learner autonomy and autonomous language learning can happen in official settings as well. If properly used, planned and applied, formal teaching can enhance learner autonomy (Ellis and Sinclair, 1989).

In the learner autonomy process, the focus is on the learner to run their own learning in the formal settings. There is a shifting of roles between teachers and students and classroom activities (Benson, 2001). Learner autonomy involves a change from teacher-centered learning setting to learner-centered one (Dam, 1995). 


\section{Teachers' Perceptions on Learner Autonomy}

Various studies have been conducted on teachers' beliefs concerning learner autonomy. Aguirre \& Speer, Austin, Borg, Calderhead, Mansour, Munby, Pajares, Prawat, Woods (as cited in Nga, 2014) claim that beliefs have great impact on different walks of life including education. Teachers' beliefs about diverse factors in education have great impact on teaching. Camilleri (1999) conducts a study on 328 teachers from six European locations (Malta, The Netherlands, Belorussia, Poland, Estonia and Slovenia). It discovers that students should be shared in decision-making about different issues in education activities, like setting the goals. Balçıkanlı (2010) investigates the opinions of 112 student teachers of English in Turkey. The results reveal that students should be engaged in naturalistic setting activities and decision making about various classroom actions as well. People, who can take responsibility of their own learning, who can make decisions, who think about the reasons behind their learning, are thought to be the most fruitful and autonomous learners.

\section{Method}

\section{Participants}

Figure (1) below presents the participants of this study consisted of 116 EFL teachers (87 males and 29 females) from different academic (Diploma, Bachelor, Master and PhD) and teaching (intermediate, secondary and university) levels. It is worth mentioning that around $90 \%$ of the participants are from the northern Iraqi cities of Erbil, sulaymaniyah and Dohuk, what is called now Iraqi Kurdistan Region. The rest is from the Iraqi capital city of Baghdad.

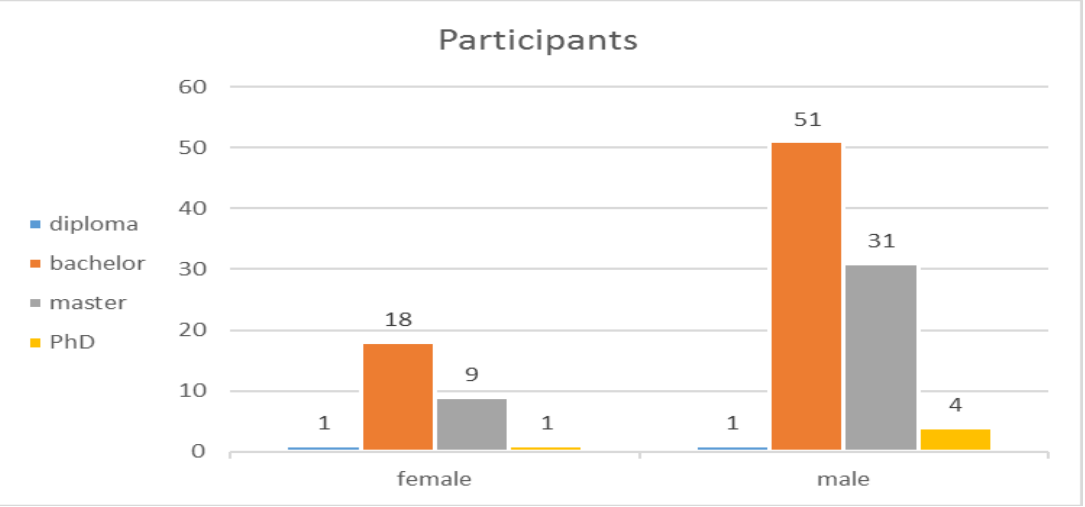

Fig. 1: Percentage level for Participant Teachers

\section{Data Collection Instruments}

The instrument used for collecting the required data is a questionnaire, which consists of two sections: the first section is a four-item demographic information. The second section is about learner autonomy 
designed by Borg \& Al-Busaidi (2012). It consists of 30 items using a fivepoint Likert scale ranging from 'strongly disagree' (one) to 'strongly agree' (five). The reason behind using a questionnaire as a tool to gather data is that questionnaires are often regarded as an easy way for gathering data in conducting a study. They can be administered to a large number of respondents in geographically diverse areas. Moreover, the study was conducted in the summer holiday of 2015 where teachers were off. So, the online questionnaire (via Google Form) was the most appropriate instrument to get the required data of the study in such time of the year.

\section{Procedure}

The process of data collection is done via an online questionnaire (Google Form) emailed to teachers. It started in August 2015 and continued for nearly a month. The questionnaire is administered to the $116 \mathrm{EFL}$ teachers with different academic levels and teaching in different educational institutions living in the three Iraqi Kurdistan Region governorates of Erbil, Duhok and Suleimaniah as well as Iraqi capital of Baghdad. For the purpose of analyzing the data, SPSS version 22 is used. The options selected by the respondents were transformed into tables displaying descriptive statistics.

\section{Findings}

The purpose of this study is to investigate Iraqi English teachers' beliefs about learner autonomy. This chapter attempts to answer the research questions posed in the introduction and reports the result of data analysis.

\section{Teachers' Beliefs About the Main Concept of Learner Autonomy}

Table 1 below presents the descriptive statistics of the first research question posed the teachers about their opinion concerning the concept of autonomy. More than a third (44 percent) of the teachers participated say that learner autonomy implies a rejection of traditional teacher-led ways of teaching with 30 percent against. The mean score is 3.1724 as illustrated in table 1 below.

Table 1: learner autonomy implies a rejection of traditional teacher-led ways of teaching

\begin{tabular}{ccccc}
\hline $\mathrm{N}$ & valid & & & 116 \\
\hline Missing & & & 0 \\
\hline Mean & & & Percent & Valid percent \\
\hline Valid & Strongly disagree & 15 & 12.9 & 12.9 \\
\hline & Disagree & 20 & 17.2 & 17.2 \\
\hline & $\begin{array}{c}\text { Neither agree nor } \\
\text { disagree }\end{array}$ & 30 & 25.9 & 25.9 \\
\hline Agree & 32 & 27.6 & 27.6 \\
\hline & Strongly agree & 19 & 16.4 & 16.4 \\
\hline
\end{tabular}




\section{Teachers' Belief About the Impact of Learner Autonomy to Second Language Learning}

Regarding learner autonomy's contribution to second language learning "Learner autonomy allows language learners to learn more effectively than they otherwise would" or the influence of autonomy on language acquisition as posed in the second research question, nearly half (66 percent) of the participants are with the concept that there is a positive relationship between learner autonomy and second language learning with mean of 3.6379 as shown in table 2 below.

Table 2: Learner autonomy allows language learners to learn more effectively than they otherwise would

\begin{tabular}{ccccc}
\hline $\mathrm{N}$ & valid & & & 116 \\
\hline & Missing & & & 0 \\
\hline Mean & & Frequency & Percent & Valid percent \\
\hline Valid & Strongly disagree & 6 & 5.2 & 5.2 \\
\hline & Disagree & 12 & 10.3 & 10.3 \\
\hline $\begin{array}{c}\text { Neither agree nor } \\
\text { disagree }\end{array}$ & 32 & 27.6 & 27.6 \\
\hline Agree & 34 & 29.3 & 29.3 \\
\hline & Strongly agree & 32 & 27.6 & 27.6 \\
\hline Total & 116 & 100.0 & 100.0 \\
\hline
\end{tabular}

\section{Teachers' Belief about the Role of Teacher in Enhancing Learner Autonomy}

After being asked to give their opinions about teachers' role in enhancing learner autonomy, almost two thirds of the participants believe that the teachers have significant role in improving learner autonomy. In other words, 68 percent of the participants agreed and strongly agreed that teachers have positive impact on learner autonomy promotion with mean value of 3.6379 as it is shown in table 3 below.

Table 3: The teacher has an important role to play in supporting learner autonomy

\begin{tabular}{ccccc}
\hline $\mathrm{N}$ & valid & & & 116 \\
\hline & Missing & & & 0 \\
\hline Mean & & Frequency & Percent & Valid percent \\
\hline Valid & Strongly disagree & 10 & 8.6 & 8.6 \\
\hline & Disagree & 17 & 14.7 & 14.7 \\
\hline & $\begin{array}{c}\text { Neither agree nor } \\
\text { disagree }\end{array}$ & 10 & 8.6 & 8.6 \\
\hline Agree & 38 & 32.8 & 32.8 \\
\hline & Strongly agree & 41 & 35.3 & 35.3 \\
\hline Total & 116 & 100.0 & 100.0 \\
\hline
\end{tabular}




\section{Teachers’ Belief About Learner Autonomy Promotion}

As far as their opinions about learner autonomy promotion are concerned, teachers believe that there are various factors that can foster autonomy. They believe that sharing students in decision making and giving them the chance of choice in some types of tasks teachers do promote learner autonomy. Furthermore, more than half of the teachers were with the concept of supporting each other's learning and collective work help students to better understand themselves and nurture their autonomy as it is shown in the table 4 below. Finally, autonomy is boosted when learners can select their own learning tools.

Table 4: Learner autonomy is promoted through activities which give learners opportunities to learn from each other

\begin{tabular}{ccccc}
\hline $\mathrm{N}$ & valid & & & 116 \\
\hline & Missing & & & 0 \\
\hline Mean & & Frequency & Percent & Valid percent \\
\hline Valid & Strongly disagree & 6 & 5.2 & 5.2 \\
\hline & Disagree & 15 & 12.9 & 12.9 \\
\hline & $\begin{array}{c}\text { Neither agree nor } \\
\text { disagree }\end{array}$ & 20 & 17.2 & 17.2 \\
\hline Agree & 40 & 34.5 & 34.5 \\
\hline & Strongly agree & 35 & 30.2 & 30.2 \\
\hline Total & 116 & 100.0 & 100.0 \\
\hline
\end{tabular}

\section{Conclusion}

This study investigated Iraqi EFL teachers' perspectives on learner autonomy in English language learning at intermediate, secondary and university level. A questionnaire, developed by Borg \& Al-Busaidi (2012), was administered on EFL teachers to collect the required data. SPSS version 19 was used to analyze teachers' opinions about learner autonomy. According to descriptive statistics, results showed that to some extent participants believed that learner autonomy implies acceptance of learnercentered learning. Besides, learner autonomy is perceived to be a key factor that fosters language learning. Teachers have a significant role in learner autonomy process as well. The study also revealed that sharing learners in decision-making and engaging them in activity choice foster autonomy. Furthermore, autonomy has been reported to be promoted from learning with each other and group work. Independent work in a self-access centre and giving learners the right to choose their own learning materials promote autonomy as well.

The results of this study support the findings of the previous research suggesting a significant correlation between learner autonomy and language learning (Borg \& Al-Busaidi, 2012). The results are also in line with Al Asmari's study (2013) that learners should be engaged in learning process. 
Moreover, the findings of the study resemble the study conducted by Camilleri (1999), on 328 teachers in six European contexts (Malta, The Netherlands,

Belorussia,

Poland, Estonia and Slovenia) regarding involving learners in decisions about learning activities, like setting the objectives of a course or selecting course content. As a result, teachers were found to be positive about involving learners in a series of activities, such as deciding on the position of desks, periodically assessing themselves and working out learning procedures. Conversely, teachers were not positive about learner involvement in the selection of textbooks and deciding on the time and place of lessons. The results are also in line with Chan's study (2003) on teacher's perspectives of learner autonomy conducted at the Hong Kong Polytechnic University in which teachers stated a clear awareness of autonomy as a goal of teaching and felt fairly positive about students' decision making abilities in different aspects of the language learning process. Teachers did feel, however, restricted by curriculum constraints and consequently did not provide decision-making opportunities for learners in areas of autonomous learning (e.g. learning objectives, activities). Further research is needed to investigate to what extent learners are encouraged to be autonomous. This study reveals that learner autonomy needs to be given more attention by the teachers to awaken the learners of the importance of autonomy and to be able to take responsibility for their own education in the learning process. So, the teachers should introduce the concept of autonomy to the learners.

\section{References:}

1. Al Asmari, A. (2013). Practices and Prospects of Learner Autonomy: Teachers’ Perceptions. English language Teaching, 6(3), 1-10.

2. Balçıkanlı, C. (2010). Learner autonomy in language learning: Student teachers' beliefs. Australian Journal of Teacher Education, 35(1), 90-103.

3. Benson, P. (2001). Teaching and Researching Autonomy in Language Learning. Harlow: Longman.

4. Benson, P. \& Voller, P. (1997). Autonomy and independence in Language Learning. London: Longman.

5. Borg, S, \& Al-Busaidi, S. (2012). Learner Autonomy: English Language Teachers' Beliefs and Practices. London. British Council.

6. Camilleri, A. (1999). Introducing Learner Autonomy in Teacher Education. Germany. Council of Europe.

7. Camilleri, G. (Ed.). (1999). Learner Autonomy: The Teachers' Views. Strassbourg: Council of Europe Publishing.

8. Chan, V. (2003). Autonomous language learning: the teachers' perspective. Teaching in Higher Education, 8(1), 33-48. 
9. Dam, L. (1995). From Theory to Classroom Practice Learner Autonomy. Dublin: Authentik Language Learning Resources.

10. Dickinson, L., (1987). Self-Instruction in Language Learning[M]. Cambridge: Cambridge University Press.

11. Ellis, G. and B. Sinclair (1989). Learning to Learn English: A Course in Learner Training. Teacher's Book. Cambridge: Cambridge University Press.

12. Holec, H. (1981). Autonomy in Foreign Language Learning. Oxford: Oxford University Press.

13. Kramsch, C. \& Sullivan, P. (1992). Appropriate pedagogy. ELT Journal, 50 (3), 199-212.

14. Little, D. (2015). Learner Autonomy and Second/Foreign language Learning. LLAS Centre for Languages, Linguistics and Area Studies, Avenue Campus, Highfield, University of Southampton, Southampton, S017 1BF. Retrieved 24 June 2015 from: https://www.llas.ac.uk/resources/gpg/1409\#ref2.

15. Little, D. (1991). Learner Autonomy 1: Definitions, Issues and Problems. Dublin: Authentik.

16. Nga, N., T. (2014). Learner Autonomy in Language Learning: Teachers' Beliefs (doctoral dissertation). Queensland University of Technology.

17. Rogers, C. (1983). Freedom to Learn. Columbus: Merrill.

18. Scharle, A., and Szabo, A., (2000). Learner Autonomy: A Guide to Developing

19. Learner Responsibility. Cambridge. Cambridge University Press.

20. Shangarffam, N., \& Ghazisaeedi, F. (2013). The Relationship among EFL Learners’ Autonomy, First Language Essay Writing Tasks and Second Language Essay Writing Tasks in Task/Content Based Language Instruction. Global Journal of Science, Engineering and Technology, 5, 197.

21. Wang, H. (2011). Promoting University English Majors' Learner Autonomy in the Chinese Context. Journal of Language Teaching and Research 2, 408-412.

22. College English Teaching Syllabus, (1999). Shanghai: Shanghai Foreign Language Education Press. 


\section{Appendix}

\section{The Questionnaire}

We would like to ask you to help us in filling out the following questionnaire concerning "Learner Autonomy". I am PhD student at Cyprus International University. The survey aims at investigating Learner Autonomy. This is not a test so there are no "right" or "wrong" answers and you do not even have to write your name on it. We are interested in your personal opinion. Please give your answers sincerely, as only this will guarantee the success of the investigation. Please be assured that all of the information obtained from will be completely confidential.

Thank you very much for your help.

Yaseen Alzeebaree

English Language Teaching

Cyprus International University

\section{Part I: personal Information}

1. your age: Click or tap to enter a date.

2. what is your gender?

Г Male

3. Female what is the highest academic degree you have earned?

Г Diploma

Г Bachekor

$\Gamma$ Master

$\Gamma \mathrm{PhD}$

4. what is the average number of students in classroom?

- $10-15$

Г $16-20$

Г $21-25$

- $26-30$

Г 31 - 35

Г $36-40$

Г $41+$

5. How many years have you been teaching?

Г 0 - 4

Г 5 - 9

Г 10-14

Г $15-19$

Г $20-24$

Г25+ 
Part II: Kindly indicate your opinion about each statement by ticking what best indicates the extent to which you disagree or agree with the statement where: $1=$ strongly disagree, $2=$ Disagree, $3=$ Neither agree nor disagree, $4=$ agree, and 5 strongly agree.

\begin{tabular}{|c|c|c|c|c|c|c|}
\hline & & $\begin{array}{l}\text { Strongly } \\
\text { disagree }\end{array}$ & Disagree & $\begin{array}{l}\text { Neither } \\
\text { agree nor } \\
\text { disagree }\end{array}$ & Agree & $\begin{array}{c}\text { Strongly } \\
\text { agree }\end{array}$ \\
\hline 1. & $\begin{array}{l}\text { Language learners of } \\
\text { all ages can develop } \\
\text { learner autonomy. }\end{array}$ & $\square$ & $\square$ & $\square$ & $\square$ & $\square$ \\
\hline 2. & $\begin{array}{l}\text { Independent study in } \\
\text { the library is an } \\
\text { activity which } \\
\text { develops learner } \\
\text { autonomy. }\end{array}$ & $\square$ & $\square$ & $\square$ & $\square$ & $\square$ \\
\hline 3. & $\begin{array}{l}\text { Learner autonomy is } \\
\text { promoted through } \\
\text { regular opportunities } \\
\text { for learners to } \\
\text { complete tasks alone. }\end{array}$ & $\square$ & $\square$ & $\square$ & $\square$ & $\square$ \\
\hline 4. & $\begin{array}{l}\text { Autonomy means } \\
\text { that learners can } \\
\text { make choices about } \\
\text { how they learn. }\end{array}$ & $\square$ & $\square$ & $\square$ & $\square$ & $\square$ \\
\hline 5. & $\begin{array}{l}\text { Individuals who lack } \\
\text { autonomy are not } \\
\text { likely to be effective } \\
\text { language learners. }\end{array}$ & $\square$ & $\square$ & $\square$ & $\square$ & $\square$ \\
\hline 6. & $\begin{array}{c}\text { Autonomy can } \\
\text { develop most } \\
\text { effectively through } \\
\text { learning outside the } \\
\text { classroom. }\end{array}$ & $\square$ & $\square$ & $\square$ & $\square$ & $\square$ \\
\hline 7. & $\begin{array}{l}\text { Involving learners in } \\
\text { decisions about what } \\
\text { to learn promotes } \\
\text { learner autonomy. }\end{array}$ & $\square$ & $\square$ & $\square$ & $\square$ & $\square$ \\
\hline 9. & $\begin{array}{l}\text { Learner autonomy } \\
\text { means learning } \\
\text { without a teacher. } \\
\text { It is harder to } \\
\text { promote learner }\end{array}$ & $\square$ & $\square$ & $\square$ & $\square$ & $\square$ \\
\hline 10. & $\begin{array}{l}\text { autonomy with } \\
\text { proficient language } \\
\text { learners than it is } \\
\text { with beginners. } \\
\text { It is possible to } \\
\text { promote learner } \\
\text { autonomy with both }\end{array}$ & $\square$ & $\square$ & $\square$ & $\square$ & $\square$ \\
\hline
\end{tabular}


young language

learners and with adults.

11. Confident language learners are more likely to develop autonomy than those who lack confidence.

12. Learner autonomy allows language learners to learn more effectively than they otherwise would.

13. Learner autonomy can be achieved by learners of all cultural backgrounds

14. Learner autonomy is promoted when learners have some choice in the kinds of activities they do.

15. Learner autonomy cannot be promoted in teacher-centred classrooms.

16. Learner autonomy is promoted through activities which give learners

opportunities to learn from each other.

17. Learner autonomy implies a rejection of traditional teacherled ways of teaching.

18. Learner autonomy cannot develop without the help of the teacher.

19. Learner autonomy is promoted by activities that encourage learners to work together.

20. Learner autonomy is promoted by independent work in a self-access centre. 
21. Learner autonomy requires the learner to be totally independent of the teacher.

22. Co-operative group work activities support the development of learner autonomy

23. Learner autonomy is promoted when learners can choose their own learning materials.

24. Learner-centred classrooms provide ideal conditions for developing learner autonomy.

25. Learning how to learn is key to developing learner autonomy

26. Learning to work alone is central to the development of learner autonomy.

27. Out-of-class tasks which require learners to use the internet promote learner autonomy.

28. The ability to monitor one's

learning is central to learner autonomy

29. Motivated language learners are more likely to develop learner autonomy than learners who are not motivated.

30. The teacher has an important role to play in supporting learner autonomy. 